2. Грибы и грибоводство / Авт.-сост. П.А. Сычёв, Н.П. Ткаченко; Под общ.ред. П.А. Сычёва. Донецк. «Издательство Сталкер», 2003. $512 \mathrm{c}$.

3. Карпов Ф.Ф., Тименков Б.М. Использование диаграммы Мольера при культивировании вешенки в теплое время года. Школа грибоводства. № 2. С. 26-28.

4. Голуб Г.А. Мікроклімат споруд для вирощування грибів. Вісник аграрної науки. 2003. № 10. С. 46-49.

5. Szudyga K. Uprawa pieczarek latom. Biuletyn «Pieczarki». 1995. No. 2. P. 11-15.

6. Entwicklung eines Verfahrens zur energiewirstschaftlichen $\mathrm{CO}_{2}-$ Oudnung von Gewachshausern durch Blogasverbrennung. Meissen, 1987. $114 \mathrm{p}$.

7. Строй А.Ф. Теплоснабжение и вентиляция сельскохозяйственных зданий и сооружений : Учеб. пособие для вузов. Киев : Вища шк., 1983. 215 с.

DOI https://doi.org/10.30525/978-9934-26-172-5-15

\title{
СЕРЕДНЬОЗВАЖЕНА СОБІВАРТІСТЬ ТЕПЛОВОЇ ЕНЕРГІЇ КОМБІНОВАНИХ ТЕПЛОГЕНЕРУЮЧИХ СИСТЕМ
}

\author{
Тесленко О. I. \\ кандидат технічних наук, \\ провідний науковий співробітник відділу ефективності \\ енерговикористання та оптимізації енергоспоживання \\ Інститут загальної енергетики \\ Національної академії наук України \\ м. Київ, Україна
}

Широке впровадження інноваційних технологій виробництва теплової енергії в існуючі системи теплопостачання України, особливо в централізовані системи, повинно проводитись 3 врахуванням наявності сформованої за багато попередніх років та сталої широкої мережі газових котелень. Ця обставина обумовлює напрям забезпечення надійності теплопостачання в умовах трансформаційного низьковуглецевого переходу із застосуванням комбінованих (гібридних) 58 
котелень, що використовують кілька типів обладнання генерації теплової енергії, як сучасних інноваційних, так і традиційних технологій.

В такій конфігурації комбінованої котельні високо капіталоємне теплогенеруюче устаткування, що, наприклад, використовує біопаливні котли або теплові насоси, для зменшення термінів повернення інвестицій повинно експлуатуватись 3 максимально можливими коефіцієнтом використання встановленої теплової потужності та максимальними обсягами виробітку теплової енергії. Менш капіталоємне теплогенеруюче устаткування, наприклад, газові водогрійні котли, які використовують високовартісний природний газ, повинно експлуатуватись тільки в піково-резервних режимах 3 мінімальними змінними операційними витратами (3 низьким коефіцієнтом використання встановленої потужності i, як наслідок, мінімальним споживанням високовартісного викопного палива).

В [1, с. 45] запропоновано в якості цільової функції оптимізації використовувати модель середньозважених річних витрат на будівництво і експлуатацію комбінованої котельні: приведені витрати (П) є сумою частки капіталовкладень (Кв), яку визначають коефіцієнти ефективності (Ен) i амортизації (f), i наступних експлуатаційних витрат (Ев).

$$
\Pi=\mathrm{K}_{\mathbf{B}} \cdot\left(\mathrm{EH}_{\mathrm{H}}+\mathrm{f}\right)+\mathrm{EB}_{\mathbf{B}}=>\min .
$$

Дослідження такої функції оптимізації на екстремум надає можливість отримати залежність для визначення задовільної частки відносної потужності інноваційного обладнання, наприклад, біопаливного котла, у комбінованій котельні при інших постійних показниках щодо виробітку теплової енергії.

У розвиток запропонованого підходу розрахункова формула $L C O E$ (англ. - Levelized Cost of Electricity) [2, с. 137] була модифікована для визначення середньозваженої собівартості виробництва теплової енергії за життєвий цикл $L_{C O H}$ ком (англ. - Levelized Cost of Heat) комбінованою (гібридною) теплогенеруючою системою (наприклад, котельнею), яка складається 3 кількох теплогенеруючих установок різного технологічного типу і теплової потужності: 


$$
L C O H_{\text {ком }}=\frac{\sum_{t=1}^{T \text { ком }} \frac{\sum_{k=1}^{K}\left(I_{t, k}\right)+\sum_{k=1}^{K}\left(M_{t, k}+F_{t, k}\right)}{(1+r)^{t}}}{\sum_{t=1}^{\text {Tком }} \frac{\sum_{k=1}^{K} H_{t, k}}{(1+r)^{t}}}
$$

де $t, T_{\text {ком }}$ - поточний рік та загальний термін життєвого циклу комбінованої котельні 3 врахуванням терміну будівництва котельні (індекс складових витрат); $k, K$ - тип та загальна кількість технологій генерації теплоенергії, які використовуються в комбінованій котельні; $\mathrm{H}_{t, k}$ - річний виробіток теплоенергії за технологією типу $k$ в поточному році $t ; \mathrm{I}_{t, k}$ - інвестиційні (капітальні) витрати за технологією типу $k$ в поточному році $t ; \mathbf{M}_{t, k}-$ умовно постійні витрати на обслуговування та ремонт теплогенеруючого обладнання за технологією типу $k$ в поточному році $t$ (не залежать від обсягу виробітку теплової енергії $\mathrm{H}_{t, k}$ та визначаються встановленою тепловою потужністю $\mathrm{N}_{k}$ ); $\mathrm{F}_{t, k}-$ змінні витрати на ресурси (паливо, електроенергію, воду, матеріали), податкові збори за викиди забруднюючих речовин тощо за технологією типу $k$ в поточному році $t$ (визначаються річним обсягом виробітку теплової енергії $\left.\mathrm{H}_{t, k}\right) ; r$ - дисконтна ставка (дисконт), що відображає швидкість здешевлення інвестиційного капіталу 3 роками протягом життєвого циклу котельні.

Об’єктом апробації модифікованої розрахункової формули була визначена комбінована водогрійна котельня загальною встановленою тепловою потужністю 13,92 Гкал/год (16,00 МВт) у складі водогрійних котлів на традиційному органічному паливі (природному газі) та водогрійних твердопаливних котлів на біомасі (тріска деревини).

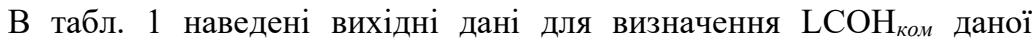
комбінованої котельні для умов іiі експлуатації в двох режимах: постачання гарячої води та обігріву помешкань будівель та споруд.

Таблиця 1

Вихідні дані для розрахунків LCOHком комбінованої котельні

\begin{tabular}{|c|c|c|c|c|c|}
\hline \multirow{2}{*}{$\mathrm{n}$} & $\begin{array}{c}\text { Найменування } \\
\text { показника }\end{array}$ & $\begin{array}{c}\text { Позна- } \\
\text { чення }\end{array}$ & $\begin{array}{c}\text { Одиниця } \\
\text { вимірю- } \\
\text { вання }\end{array}$ & $\begin{array}{c}\text { Газовий } \\
\text { котел }\end{array}$ & $\begin{array}{c}\text { Біопалив- } \\
\text { ний котел }\end{array}$ \\
\hline 1 & \multicolumn{5}{|c|}{ Технічні та виробничі показники } \\
\hline 1.1 & $\begin{array}{c}\text { Загальна теплова } \\
\text { потужність котельні }\end{array}$ & ком & $\begin{array}{c}\text { Гкал/год } \\
\text { (МВт) }\end{array}$ & $\begin{array}{c}13,92 \\
(16,00)\end{array}$ & \\
\hline
\end{tabular}


Продовження таблиці 1

\begin{tabular}{|c|c|c|c|c|c|}
\hline № & $\begin{array}{c}\text { Найменування } \\
\text { показника }\end{array}$ & $\begin{array}{l}\text { Позна- } \\
\text { чення }\end{array}$ & $\begin{array}{c}\text { Одиниця } \\
\text { вимірю- } \\
\text { вання }\end{array}$ & $\begin{array}{c}\text { Газовий } \\
\text { котел }\end{array}$ & $\begin{array}{l}\text { Біопалив- } \\
\text { ний котел }\end{array}$ \\
\hline 1 & \multicolumn{5}{|c|}{ Технічні та виробничі показники } \\
\hline 1.2 & $\begin{array}{c}\text { Теплова потужність } \\
\text { для опалення }\end{array}$ & Noп & $\begin{array}{c}\text { Гкал/год } \\
\text { (МВт) }\end{array}$ & $\begin{array}{c}10,12 \\
(11,63) \\
\end{array}$ & $\begin{array}{c}\text { за потребами } \\
\text { споживача }\end{array}$ \\
\hline 1.3 & $\begin{array}{c}\text { Теплова потужність } \\
\text { для гарячого } \\
\text { водопостачання }\end{array}$ & Nгв & $\begin{array}{c}\text { Гкал/год } \\
(\text { МВт) }\end{array}$ & $\begin{array}{c}2,53 \\
(2,91)\end{array}$ & $\begin{array}{c}0,2 \cdot\left(\mathrm{Non}^{+}\right. \\
\text {Nгв })\end{array}$ \\
\hline 1.4 & $\begin{array}{c}\text { Теплова потужність } \\
\text { для резервування }\end{array}$ & $\mathrm{Np} 3$ & $\begin{array}{c}\text { Гкал/год } \\
\text { (МВт) }\end{array}$ & $\begin{array}{c}1,10 \\
(1,46)\end{array}$ & $\begin{array}{c}0,1 \cdot\left(\mathrm{Non}^{+}\right. \\
\text {Nгв })\end{array}$ \\
\hline 1.5 & $\begin{array}{c}\text { Співвідношення } \\
\text { потужності біокотла } \\
\text { до загальної } \\
\text { потужності котельні }\end{array}$ & $\begin{array}{l}\text { Nбк } \\
\text { / Кком }\end{array}$ & - & $\begin{array}{c}0,0-1,03 \\
\text { інтервалом } \\
0,1\end{array}$ & \\
\hline 1.6 & $\begin{array}{c}\text { Річний виробіток } \\
\text { теплової енергії на } \\
\text { обігрів }\end{array}$ & Qоп & Гкал/рік & 18167 & $\begin{array}{c}\text { За графіком } \\
\text { Россандера } \\
\text { [3] }\end{array}$ \\
\hline 1.7 & $\begin{array}{c}\text { Річний виробіток } \\
\text { теплової енергії на } \\
\text { гаряче } \\
\text { водопостачання }\end{array}$ & Qгв & Гкал/рік & 21900 & $\begin{array}{l}\text { Noп x } 8760 \\
\text { год/рік }\end{array}$ \\
\hline 1.8 & $\begin{array}{c}\text { Річний загальний } \\
\text { виробіток теплової } \\
\text { енергії }\end{array}$ & Qзаг & Гкал/рік & 40067 & Qоп + Qгв \\
\hline 1.9 & $\begin{array}{c}\text { Коефіцієнт корисної } \\
\text { дії газового та } \\
\text { біопаливного котлів }\end{array}$ & $\begin{array}{l}\text { ККД гк, } \\
\text { ККД бк }\end{array}$ & $\%$ & 93 & 86 \\
\hline 1.10 & $\begin{array}{c}\text { Теплотворна } \\
\text { здатність палива } \\
\text { (природного газу, } \\
\text { тріски деревини) } \\
\end{array}$ & $\begin{array}{l}\mathrm{Q}_{\mathrm{H}}^{\mathrm{p}} \mathrm{\Pi \Gamma}, \\
\mathrm{Q}_{\mathrm{H}}^{\mathrm{p}} \mathrm{Tд},\end{array}$ & $\begin{array}{c}\text { ккал/ } \mathbf{M}^{3}, \\
\text { ккал/кг }\end{array}$ & 8050 & 2600 \\
\hline 1.11 & $\begin{array}{c}\text { Споживання } \\
\text { електроенергії } \\
\text { (разом } 3 \\
\text { екологозахисним } \\
\text { обладнанням) }\end{array}$ & $\mathrm{Ce} / \mathrm{e}$ & кВт·год/Гкал & 8 & 36 \\
\hline 2 & \multicolumn{5}{|c|}{ Технічні та виробничі показники } \\
\hline 2 & $\begin{array}{l}\text { Економічні } \\
\text { показники }\end{array}$ & & & & \\
\hline 2.1 & $\begin{array}{c}\text { Питомі капітальні } \\
\text { витрати, } \\
\text { враховуючи } \\
\text { основне та } \\
\text { допоміжне } \\
\text { обладнання, } \\
\text { проектні, монтажні } \\
\text { та налагоджувальні } \\
\text { роботи }\end{array}$ & $\begin{array}{l}\text { КВгк } \kappa^{\text {пит }}, \\
\text { КВбк }\end{array}$ & $\$ / \kappa B \mathrm{~T}$ & 45 & 175 \\
\hline
\end{tabular}


Закінчення таблиці 1

\begin{tabular}{|c|c|c|c|c|c|}
\hline № & $\begin{array}{c}\text { Найменування } \\
\text { показника }\end{array}$ & $\begin{array}{l}\text { Позна- } \\
\text { чення }\end{array}$ & $\begin{array}{c}\text { Одиниця } \\
\text { вимірю- } \\
\text { вання } \\
\end{array}$ & $\begin{array}{c}\text { Газовий } \\
\text { котел }\end{array}$ & $\begin{array}{l}\text { Біопалив- } \\
\text { ний котел }\end{array}$ \\
\hline 2.2 & Термін будівництва & Т буд & рік & 1 & 1 \\
\hline 2.3 & Термін експлуатації & Т екс & рік & 20 & 20 \\
\hline 2.4 & $\begin{array}{c}\text { Витрати на } \\
\text { ремонтно- } \\
\text { профілактичне } \\
\text { обслуговування } \\
\text { (відсоток від } \\
\text { капітальних витрат) }\end{array}$ & Рем & $\%$ & 5 & 5 \\
\hline 2.5 & $\begin{array}{c}\text { Адміністративні } \\
\text { витрати, разом з } \\
\text { фондом оплати } \\
\text { праці (враховуючи } \\
\text { збори та } \\
\text { відрахування) } \\
\end{array}$ & Ад & $\%$ & 1 & 3 \\
\hline 2.6 & $\begin{array}{c}\text { Робочі дні гарячого } \\
\text { водопостачання } \\
\text { (ГВП) на рік }\end{array}$ & Др гвп & днів & 360 & $\begin{array}{c}\text { ГВП (5 днів } \\
\text { на ремонтне } \\
\text { обслуговува } \\
\text { ння) } \\
\end{array}$ \\
\hline 2.7 & $\begin{array}{c}\text { Робочі дні обігрів } \\
\text { на рік }\end{array}$ & Др обігрів & днів & 181 & обігрів \\
\hline 2 & \multicolumn{5}{|c|}{ Технічні та виробничі показники } \\
\hline 2.8 & Годин у добі & Т доб & год & 24 & \\
\hline 2.9 & $\begin{array}{c}\text { Вартість } \\
\text { електроенергії }\end{array}$ & $\mathrm{C}$ ee & \$МВт·год & 70 & 70 \\
\hline 2.10 & $\begin{array}{c}\text { Вартість палива (3 } \\
\text { постачанням) }\end{array}$ & С пг, Стд & $\begin{array}{c}\text { \$/тис. } \mathrm{M}^{3}, \\
\$ / \mathrm{T}\end{array}$ & 350 & 45 \\
\hline 2.11 & $\begin{array}{c}\text { Ставка } \\
\text { дисконтування }\end{array}$ & $\mathrm{Cdic}$ & $\%$ & 5 & 5 \\
\hline 2.12 & Курс валюти & Квал & $\begin{array}{l}\text { грн } / \$ \\
\text { США } \\
\end{array}$ & 28 & 28 \\
\hline
\end{tabular}

Примітка. Загально - виробничі затрати на котельні при розрахунку $\mathrm{LCOH}_{\text {ком }}$ не враховувались у змінних та умовно - постійних витратах. 


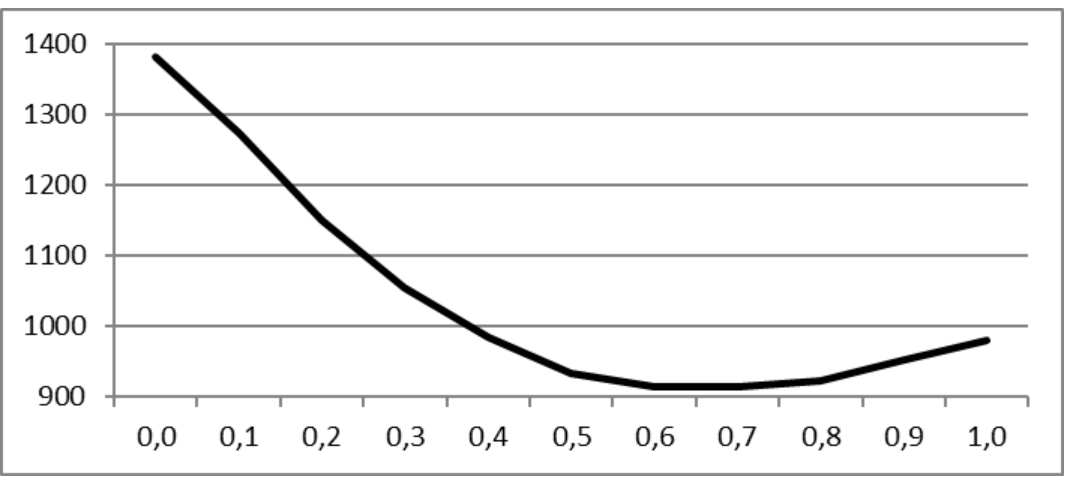

\section{Рис. 1. Вплив співвідношення бк /Nком на $\mathrm{LCOH}_{\kappa o м}$ для комбінованої котельні, грн/Гкал}

Графік тривалості теплового навантаження (графік Росандера) та інтегральна крива розподілу виробітку теплової енергії комбінованою бівалентною котельнею з двома джерелами теплової енергї визначались за рекомендаціями [3, с. 42-43].

Розподіл річного виробітку теплової енергії біопаливним котлом комбінованої бівалентної котельні в залежності від його відносної теплової потужності при різному навантаженні на гаряче водопостачання визначався за допомогою графіка, наведеного в [4, с.82].

Біопаливні котли експлуатуються в режимі гарячого водопостачання протягом всього року і основну частину теплопостачання для обігріву помешкань будівель. Газові котли використовуються в піковорезервному режимі для забезпечення теплопостачання для обігріву помешкань будівель в опалювальний період підчас мінімальних температур зовнішнього повітря.

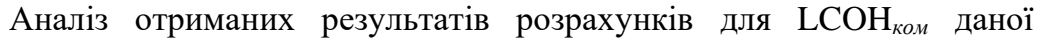

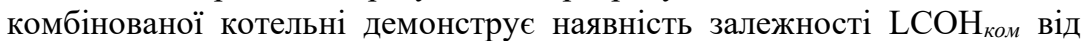
структури технологічного виробництва теплової енергії : від співвідношення потужності біопаливного котла (котлів) до загальної теплової потужності цієї котельні Nбк/Nком 3 екстремумом (мінімальним значенням) в діапазоні значень 0,5-0,7 (рис. 1).

Такий підхід дозволяє загалом оптимізувати технологічну структуру комбінованих котелень для мінімізації середньозваженої собівартості теплової енергії за життєвий цикл. 


\section{Література:}

1. Колиенко А.Г. Оптимизация тепловой мощности котлов на биотопливе в составе комбинированных котельных. ГАЗинформ, 2013, № 4, C.44 - 46.

2. Renewable Power Generation Costs in 2019. Annex I . Cost metric methodology. International Renewable Energy Agency (IRENA). 2020, 144 p.

3. Крамар В.Г. Побудова графіка тривалості теплового навантаження (графіка Росандера) для регіонів України. Промислова теплотехніка, 2018, т. 40, № 4, с. 41-49.

4. Біоенергетичні проекти від ідеї до втілення. Практичний посібник / Під заг. редакцією Тормосова Р. Ю. - К.: ТОВ «Поліграф плюс», 2015. 208 c. 